\title{
In Situ Transesterification of Wet Marine and Fresh Water Microalgae for Biodiesel Production and Its Effect on the Algal Residue
}

\author{
Kamoru A. Salam ${ }^{1}$, Sharon B. Velasquez-Orta ${ }^{2}$, Adam P. Harvey ${ }^{2}$ \\ ${ }^{1}$ Department of Chemical Engineering, Faculty of Engineering, University of Abuja, Abuja, Nigeria \\ ${ }^{2}$ School of Chemical Engineering and Advanced Materials (CEAM), University of Newcastle upon Tyne, \\ Newcastle upon Tyne, UK \\ Email: "kamorusalam@gmail.com
}

Received 25 February 2016; accepted 3 May 2016; published 6 May 2016

Copyright @ 2016 by authors and Scientific Research Publishing Inc.

This work is licensed under the Creative Commons Attribution International License (CC BY). http://creativecommons.org/licenses/by/4.0/

c) (i) Open Access

\section{Abstract}

This article reports a high yielding technique of synthesizing zirconium dodecyl sulphate ("ZDS") for in situ transesterification of Nannochloropsis occulata and Chlorella vulgaris for fatty acid methyl ester (FAME) production. ZDS produced a significantly higher FAME yield in $\boldsymbol{N}$. occulata than in $C$. vulgaris $(\mathrm{p}=\mathbf{0 . 0 0 8})$. The varying performance of ZDS in the two species could be due to their different cell wall chemistries. Sodium dodecyl sulphate (SDS) in $\mathrm{H}_{2} \mathrm{SO}_{4}$ for FAME enhancement from the two species was also studied. Treatment with SDS in $\mathrm{H}_{2} \mathrm{SO}_{4}$ increased the FAME production rate in both species. Residual protein content after the in situ transesterification in $C$. vulgaris and $N$. occulata reduced respectively by $6.5 \%$ and $10 \%$. The carbohydrate content was reduced by $71 \%$ in C. vulgaris and $65 \%$ in $N$. occulata. The water tolerance of the process when using $\mathrm{H}_{2} \mathrm{SO}_{4}$, with or without SDS, was evaluated by hydrating the two species with $10 \%-30 \%$ distilled water ( $w / w$ dry algae). The FAME concentration began to diminish only at $30 \%$ water content in both species. Furthermore, the presence of a small amount of water in the biomass or methanol increased the lipid extraction efficiency, improving the FAME yield, rather than inhibiting the reaction.

\section{Keywords}

Biodiesel (Fatty Acid Methyl Ester), Cell Wall, In Situ Transesterification, Surfactant, Surfactant Catalyst, Wet Microalgae

\footnotetext{
Corresponding author.
}

How to cite this paper: Salam, K.A., Velasquez-Orta, S.B. and Harvey, A.P. (2016) In Situ Transesterification of Wet Marine and Fresh Water Microalgae for Biodiesel Production and Its Effect on the Algal Residue. Journal of Sustainable Bioenergy Systems, 6, 17-30. http://dx.doi.org/10.4236/jsbs.2016.62003 


\section{Introduction}

Environmental concerns and energy security contribute to the global increase in biodiesel. Different biodiesel feedstocks have been explored, including food oil crops [1], non-food oil crop such as Jatropha curcas [2] and microalgae [3]-[5]. Food oil crops are not sustainable, as freshwater and considerable hectares of arable land are required for their cultivation [6]. Non-food oil crops and waste oil can only supply limited quantities of biofuels, so cannot meet world transport fuels requirements.

Biodiesel can be produced from microalgae through reactive extraction ("in situ transesterification”) or a twostep transesterification. In a two-step transesterification, pre-extracted oil from microalgae can be converted into fatty acid methyl ester (FAME) ("biodiesel”) with alkalised or acidified methanol. Alternatively, algal FAME can be produced via in situ transesterification by contacting the algal biomass directly with an alcohol containing a catalyst [3]-[5]. It is potentially a cost-effective alternative way of producing algal FAME due to its elimination of the solvent extraction step and its higher water tolerance [3]-[5] as the solvent extraction and drying steps account for $\sim 90 \%$ of the process energy in a two-step transesterification of algal oil to FAME [7].

Despite the advantages of microalgae oil as biodiesel feedstock, algal biodiesel production is still at laboratory scale due to technical challenges required to be solved to make it economical and sustainable [8]. Indeed complete drying of microalgae to the level required by two steps transesterification is energy intensive and contributes to the blockage in commercialisation of algal biodiesel. A water tolerant FAME extraction, perhaps by increasing the water tolerance of the reaction step [9] will contribute to the reduction in drying costs. In addition, efficient utilisation of algal residue for biogas production has been suggested as an approach to improve economy of algal biofuel [8]. Whole algae or spent lipid-extracted algal residue has been shown to be feasible for producing biogas via anaerobic digestion [10] [11] but little or no information are available in the literature on the use of algal residue obtain from in situ transesterification for biogas production. In situ transesterification has different process conditions with lipid extraction due to different solvent and inclusion of catalyst in in situ transesterification. Therefore, algal residue obtained from lipid-extracted microalgae and reactive extracted microalgae are expected to be different.

In situ transesterification are usually catalysed with homogeneous $\mathrm{NaOH}$ and $\mathrm{H}_{2} \mathrm{SO}_{4}$. When $\mathrm{H}_{2} \mathrm{SO}_{4}$ is used, a high concentration of the catalyst is always required to achieve high FAME yield [3] [12] [34]. However, the need to neutralise the unreacted acid in the product streams will increase operating costs to some extent. A surfactant catalyst, cerium (III) trisdodecyltrihydrate, has been shown to promote transesterification of triglycerides and esterification of free fatty acids [13]. Inclusion of sodium dodecyl sulphate (SDS) in water has been reported to increase oil extraction from canola seeds [14]. Considering the fact that SDS is a surfactant used for lysing cells to recover intracellular components [15], its inclusion in acid catalyst could increase in situ transesterification FAME production yield/rate [9].

This article compares the effect of SDS in $\mathrm{H}_{2} \mathrm{SO}_{4}$ or zirconium dodecyl sulphate (ZDS) to catalyse in situ transesterification for FAME enhancement in $N$. occulata and C. vulgaris. These two species are selected due to their large scale cultivation history, and their varying cell wall chemistries. ZDS is a "Lewis acid-surfactantcombine" catalyst and its cell wall disruption for FAME enhancement is explored. Furthermore, the effect of including SDS in $\mathrm{H}_{2} \mathrm{SO}_{4}$ on the water tolerance of the in situ transesterification of both microalgae was evaluated. This is important, as complete drying of microalgae is energy intensive and render algal biodiesel production uneconomical and unsustainable. Small amounts of water have been reported to significantly decrease conversion during two step transesterification of vegetable oil [16]. The effect of the process conditions of in situ transesterification on the residual protein and carbohydrate is studied to check the potential of utilizing the residual microalgae for biogas production. This has not been investigated in the literature.

\section{Material and Methods}

\subsection{Microalgae Culture and Their Major Biochemical Compositions}

Concentrated wet $N$. occulata was purchased from Varicon Aqua Solutions (London, UK). A frozen sample was freeze dried at $-40^{\circ} \mathrm{C}$ for $\sim 24 \mathrm{~h}$ in a ThermoModulyo D Freeze Dryer. C. vulgaris was purchased in dried form from Chlorella Europe, UK. The two species were further dried at $60^{\circ} \mathrm{C}$ in a moisture analyser to preserve its biochemical compositions [17] until a constant mass. The moisture content of the resulting dried microalgae was taken as the reference i.e. $0 \%$ moisture ( $\mathrm{w} / \mathrm{w}$ dry algae). The total lipids content were measured by Folch et al. 
[18]. The carbohydrate contents of both species were measured by acid digestion [19]. Elemental (CHN) analysis was measured with a Carlo Erba 1108 elemental analyser. After that, their protein content were calculated by multiplying the nitrogen content with a factor 4.75, the nitrogen-protein conversion factor for microalgae of Lourenc et al. [20]. The free fatty acid (FFA) and cell wall lipids (phospholipids and glycolipids) of both species were measured using the solid phase extraction method [21].

\subsection{Determination of Maximum FAME Content}

The maximum FAME concentration in each sample was quantified using Garces and Mancha's method [22]. A methylating mixture of methanol, toluene, 2, 2-dimethoxypropane, and sulphuric acid at a volumetric ratio of 39:20:5:2 was prepared. The mixture was then thoroughly mixed using a vortex mixer. A homogeneous mixture containing $3.3 \mathrm{~mL}$ of the methylating mixture and $1.7 \mathrm{~mL}$ of heptane was added to $0.2 \mathrm{~g}$ of each sample of the microalgae and vortexed well. After this, the mixture was trans esterified in an IKA incubator at $60^{\circ} \mathrm{C}$; $450 \mathrm{rpm}$ for $12 \mathrm{~h}$. The sample was then kept in a freezer to quench the reaction. The resulting upper FAME layer was carefully pipetted into a pre-weighed centrifuge tube and weighed. A $0.1 \mathrm{~mL}$ of an internal standard solution: methyl heptadecanoate (Sigma Aldrich, UK, $10 \mathrm{mg} /(\mathrm{mL}$ methanol) was mixed with the upper FAME layer and stirred thoroughly to form homogeneous mixture. $1 \mu \mathrm{L}$ of the homogeneous mixture was injected into the GC and data was collected using Data Apex Clarity software, UK as explained in the section 2.6. The maximum FAME content in the sample was calculated by multiplying the FAME concentration obtained by the mass of the upper FAME layer.

\subsection{Catalyst Synthesis}

Zirconium (IV) dodecyl sulphate $\left(\mathrm{Zr}\left[\mathrm{OSO}_{3} \mathrm{C}_{12} \mathrm{H}_{25}\right]_{4}\right.$ ) was synthesized according to the method used by Salam et al. [9]. FTIR spectra of SDS and ZDS were recorded on a Varian 800 FT IR. FT IR spectrum of sodium dodecyl sulphate was compared with that of zirconium dodecyl sulphate synthesized for structure confirmation [13].

\subsection{Quantification of Cell Disruption after in Situ Transesterification}

The amount of chlorophyll extracted from the microalgae has been correlated with cell wall disruption [23]. The total chlorophyll A, B and C obtained after the in situ transesterification by the different catalysts was measured using a modification of Gerde et al.'s method [23]. To study the extent of cell disruption of the C. vulgaris and $N$. occulata, $0.47 \mathrm{~mL}$ of methanol was added to a $100 \mathrm{mg}$ of dried microalgae in a $2.5 \mathrm{~mL}$ tube followed by $100 \% \mathrm{H}_{2} \mathrm{SO}_{4}$ (w/w oil). To another tube containing the same amount of microalgae, methanol and $\mathrm{H}_{2} \mathrm{SO}_{4}, 9 \mathrm{mg}$ sodium dodecyl sulphate (SDS) was added to study the effect on cell disruption of including SDS in $\mathrm{H}_{2} \mathrm{SO}_{4}$. A third test tube was used with $100 \%$ ZDS (w/w lipids), $100 \mathrm{mg}$ of microalgae and $0.47 \mathrm{~mL}$ of methanol. The reactions were allowed to progress for $24 \mathrm{~h}$, at $32^{\circ} \mathrm{C}$ to avoid degradation of the chlorophyll at a stirring rate of 450 rpm using IKA KS 4000 icontrol incubator shaker (IKA, Germany). At the end of the reaction, the samples were centrifuged at 17,000 g for 10 min using Accu Spin Micro 17 centrifuge (Fisher Scientific, UK). Methanol was used as blank. The absorbance of the supernatant obtained was measured at 664, 647, and $630 \mathrm{~nm}$ and the chlorophyll concentrations in $\mu \mathrm{g} /(\mathrm{mL})$ were calculated using the Jeffrey and Humphrey (1975) formulae [24]:

$$
\begin{gathered}
\text { Chla }=11.93 A_{664}-1.93 A_{647} \\
\text { Chlb }=-5.5 A_{664}+20.36 A_{647} \\
\text { Chlc }=-3.73 A_{664}+24.36 A_{630}
\end{gathered}
$$

where:

Chla is chlorophyll a,

Chlb is chlorophyll b,

Chlc is chlorophyll c.

\subsection{Experimental Designs}

A8.5 mol. $\mathrm{H}_{2} \mathrm{SO}_{4} /$ (mol. lipids) which equals to $100 \%$ (w/w lipids) was used. Zirconium dodecyl sulphate (“ZDS”) was fixed as $100 \%$ ZDS (w/w lipids). These amounts of catalysts used in this study were based on the 
optimum of $100 \% \mathrm{H}_{2} \mathrm{SO}_{4}$ (w/w oil) reported by Ehimen et al. [25]. A $9 \mathrm{mg}$ of sodium dodecyl sulphate was added to the $\mathrm{H}_{2} \mathrm{SO}_{4}$ to study the effect of combination of a surfactant and homogeneous $\mathrm{H}_{2} \mathrm{SO}_{4}$ catalyst on FAME yield. This amount of SDS is significantly greater than $2 \mathrm{~mol}$. SDS/(mol. oil) reported to be enough to solubilise the phospholipid bilayer [26]. The molar ratio of methanol to lipid was 600:1, which equals to 0.0047 $\mathrm{mL} /\left(\mathrm{mg}\right.$ algae cells). A temperature of $60^{\circ} \mathrm{C}$ was used for all the experiments as most previous reports on in situ transesterification of microalgae were optimised at $60^{\circ} \mathrm{C}$ when methanol is used as solvent [4] [5] [27]. A $880 \mathrm{~g} /$ (mol.) was the average molecular mass of the oil used to calculate the entire molar ratios. Rehydrated samples of $N$. occulata and $C$. vulgaris were prepared by adding $10 \%, 20 \%$, and $30 \%$ distilled water (w/w dry algae), then allowing the samples to equilibrate for $1 \mathrm{~h}$. The resulting wet biomass was then transesterified using $\mathrm{H}_{2} \mathrm{SO}_{4}$, with or without SDS, to isolate the water tolerance effect. All in situ transesterification were conducted in $15 \mathrm{~mL}$ glass tubes containing $100 \mathrm{mg}$ of microalgae. The tubes were loaded in an IKA KS 4000 icontrol incubator shaker (IKA, Germany) and kept at a constant temperature of $60^{\circ} \mathrm{C}$. A high stirring rate of $450 \mathrm{rpm}$ was used to prevent mass transfer limitations. The acid catalyst in each sample taken at each specified in situ transesterification was neutralised with calcium oxide $(\mathrm{CaO})$ to quench the reaction. The biomass was separated from the liquid by centrifugation. The biodiesel filtrate (a mixture of methanol, FAME and by-products) was stored in pre-weighed tubes and weighed. The FAME concentration in the biodiesel filtrate was measured by gas chromatography, as explained in section 2.6.

\subsection{Analytical Techniques}

The European standard procedure [28] was used to determine the FAME concentration after the in situ transesterification. The biodiesel filtrate was mixed with $0.1 \mathrm{~mL}$ of an internal standard solution: methyl heptadecanoate (Sigma Aldrich, UK, $10 \mathrm{mg} /(\mathrm{mL}$ methanol) in $2 \mathrm{~mL}$ vials. $1 \mu \mathrm{L}$ of the homogeneous mixture was injected into the GC and data was collected using Data Apex Clarity software, UK. The gas chromatography, GC was set to the following conditions: carrier gas: helium, $4.8 \times 10^{4} \mathrm{~Pa}$; air pressure, $2.2 \times 10^{5} \mathrm{~Pa}$; hydrogen pressure, 1.5 $\times 10^{5} \mathrm{~Pa}$; a capillary column head pressure was adjusted to $3.1 \times 10^{4} \mathrm{~Pa}$. The oven temperature was maintained at $230^{\circ} \mathrm{C}$ for 25 minutes. Heat rate was $15^{\circ} \mathrm{C} / \mathrm{min}$; initial temperature was set at $150^{\circ} \mathrm{C}$ and held for $2 \mathrm{~min}$; final temperature was set at $210^{\circ} \mathrm{C}$ and held for $20 \mathrm{~min}$; injection temperature was $250^{\circ} \mathrm{C}$ while detector temperature was $260^{\circ} \mathrm{C}$. The biodiesel rich filtrate was mixed with $0.2 \mathrm{~mL}$ of an internal standard solution: methyl heptadecanoate (Sigma Aldrich, UK, $10 \mathrm{mg} /(\mathrm{mL}$ methanol) in $2 \mathrm{~mL}$ vials. $1 \mu \mathrm{L}$ of the homogeneous mixture was injected into the GC using $10 \mu \mathrm{l}$ micro syringe (SGE, Australia) and data was collected using Data Apex Clarity software, UK. The column used was CP WAX 52 CB $30 \mathrm{~m} \times 0.32 \mathrm{~mm}(0.25 \mu \mathrm{m})$ (Agilent, Netherlands).The mass of FAME obtained in the biodiesel-rich phase from the experiments was calculated by multiplying the mass of the final biodiesel mixture obtained and the FAME concentration measured by the GC. The FAME yield was calculated by dividing the mass of FAME obtained by the maximum FAME available in the algae.

$$
\text { FAME Concentration }(\mathrm{C})=\frac{\left(\sum A\right)-A_{E i}}{A_{E i}} \times \frac{C_{E i} V_{E i}}{m} \times 100 \%
$$

where:

$\sum A$ are the total peak areas from C8:0-C20:1.

$A_{E i}$ is the peak area of the methyl heptadecanoate.

$V_{E i}$ is the volume in $\mathrm{ml}$ of the methyl heptadecanoate used.

$C_{E i}$ is the concentration in $\mathrm{mg} /(\mathrm{mL}$ of the methyl heptadecanoate solution), and

$m$ is the mass of the sample in $\mathrm{mg}$.

The mass of the methyl ester in the sample was calculated by multiplying the FAME concentration (C) with the mass of the biodiesel reach filtrate from the in situ transesterification.

$$
\text { Mass of the methyl ester }(\mathrm{mg})=\mathrm{C}(\%) \times w(\mathrm{mg})
$$

Where $w$ is the mass of the biodiesel filtrate

Yield $(\% \mathrm{w} / \mathrm{w})$ was the determined by comparing the mass of methyl ester obtained with the maximum FAME in the sample.

$$
\text { Yield }(\% \mathrm{w} / \mathrm{w})=\frac{\text { Mass of methyl ester from the experiments }(\mathrm{mg})}{\text { Mass of the maximum FAME in the sample }(\mathrm{mg})} \times 100 \%
$$




\subsection{Statistical Analysis}

An independent sample t-test was conducted to determine whether there is a significant difference i.e. $(\mathrm{p}<0.5)$ between:

1) Means FAME yields obtained in $N$. occulata and C. vulgaris when $\mathrm{H}_{2} \mathrm{SO}_{4}, \mathrm{H}_{2} \mathrm{SO}_{4}+\mathrm{SDS}$ and ZDS were used for the in situ transesterification.

2) Means chlorophyll extracted in $N$. occulata and C. vulgaris when $\mathrm{H}_{2} \mathrm{SO}_{4}, \mathrm{H}_{2} \mathrm{SO}_{4}+\mathrm{SDS}$, ZDS and the control i.e. when no catalyst was used.

\section{Results and Discussion}

\subsection{Catalyst Synthesis and Characterization}

Zirconium (IV) dodecyl sulphate $\left(\mathrm{Zr}\left[\mathrm{OSO}_{3} \mathrm{C}_{12} \mathrm{H}_{25}\right]_{4}\right)$ was synthesized by method used by Salam et al. [9]. It involves inclusion of $4 \% \mathrm{KCl}$ (w/w zirconium dodecyl sulphate solution) which significantly increased the yield of Zirconium (IV) dodecyl sulphate. This approach is a new method we developed and is fundamentally different from what was reported by Zolfigol et al. [29]. The infrared spectrum of zirconium dodecyl sulphate (ZDS) was compared with that of sodium dodecyl sulphate (SDS) because the major difference between them is the zirconium and sodium cation. The spectra of the two compounds are shown in Figure 1.

It can be seen that the spectra of the two compounds are very similar, which is expected because of the dodecyl group they have in common. However, the shifting and splitting observed in the zirconium dodecyl sulphate head group region (1213-576 $\mathrm{cm}^{-1}$ ), when compared to sodium dodecyl sulphate, is an indication of the interaction of dodecyl sulphate anions with a more electronegative substituent $\left(\mathrm{Zr}^{4+}\right)[30]$.

Table 1 shows the functional groups assigned to stretching and bending vibration modes of the dodecyl sulphate alkyl chain and the head groups. The SDS spectrum obtained is similar to what was reported by Ghesti et al. [13]. All the listed functional groups can be seen in the ZDS and SDS compounds, confirming to some degree that the compound synthesised is ZDS.

\subsection{In Situ Transesterification Using $\mathrm{H}_{2} \mathrm{SO}_{4}$}

The amount of total lipids in $N$. occulata was determined as $17 \% \pm 0.8 \%$ (w/w dry algae) while that of $C$. vulgaris was $15 \% \pm 0.9 \%$ (w/w dry algae). The free fatty acid (FFA) content in the total lipids of $N$. occulata and $C$. vulgaris were determined as $18.3 \% \pm 2.4 \%$ (w/w total lipids) and $6.1 \% \pm 0.3 \%$ (w/w total lipids), respectively. These levels of FFA necessitate the use of acid rather than base catalysts. Lotero et al. [33] reported an upper limit of $0.5 \%$ FFA content to prevent saponification for conventional alkaline transesterification. The maximum

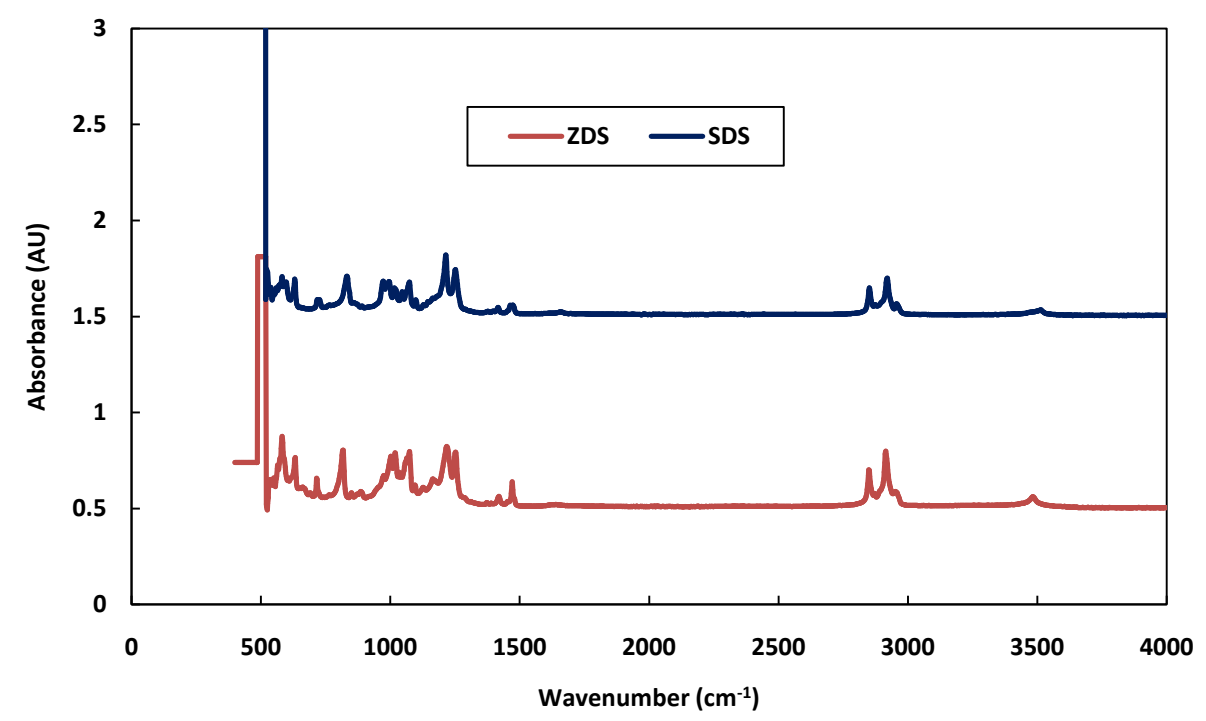

Figure 1. FTIR spectra of sodium dodecyl sulphate (SDS) and zirconium dodecyl sulphate (ZDS). 
Table 1. FTIR band assigned for ZDS and SDS.

\begin{tabular}{ccc}
\hline Wavenumber $\left(\mathrm{cm}^{-1}\right)$ & Assignments & Reference \\
2937 & asymmetric $\left(\mathrm{CH}_{3}\right)$ & {$[31]$} \\
2915 & asymmetric $\left(\mathrm{CH}_{2}\right)$ & {$[31]$} \\
2848 & symmetric $\left(\mathrm{CH}_{2}\right)$ & {$[31]$} \\
830 & $\mathrm{~S}-\mathrm{OC}$ stretching & {$[31]$} \\
968, & asymmetric S-OC stretching & {$[32]$} \\
977 & & {$[32]$} \\
1068, & degenerate $\mathrm{OSO}_{3}^{-}$symmetric stretching & {$[32]$} \\
1213, & degenerate $\mathrm{OSO}_{3}^{-}$asymmetric stretching & \\
576, & degenerate $\mathrm{Symmetric}^{-} \mathrm{OSO}_{3}^{-}$bending & \\
603 &
\end{tabular}

FAME yield as shown in Figure 2 was $57.5 \% \pm 3.6 \%$ for $C$. vulgaris and $53.8 \% \pm 8 \%$ for $N$. occulata, occurring at $24 \mathrm{~h}$.

Clearly the initial rate of FAME production is significantly higher for $C$. vulgaris, but there was no significant difference between the final transesterifiable lipid yields of the two species. The FAME time profile seems to have 2 distinct stages, indicating 2 distinct, possibly sequential, processes. In C. vulgaris, $\sim 85 \%$ of the final yield is achieved in the initial rapid extraction/reaction stage, whereas in $N$. occulata only $~ 50 \%$ is produced during this time period. Perhaps this represents two different locations of transesterifiable matter e.g. the internal oil bodies and the cell wall lipids.

Increasing the acid concentration to $0.15 \mu \mathrm{L} /(\mathrm{mg}$ algae) resulted in a $17 \%$ and $62 \%$ increase in FAME yield for C. vulgaris and $N$. occulata respectively in $24 \mathrm{~h}$. A 53\% increase in FAME yield during $\mathrm{H}_{2} \mathrm{SO}_{4}$-catalysed in situ transesterification of Spirulina-platensis was observed by increasing acid volume from 0.0016 to $0.19 \mu \mathrm{L} /$ (mg algae) [12]. Other researchers also reported increases in the yield of biodiesel with an increase in acid concentration during acid catalysed in situ transesterification of microalgae [3] [34]. One probable reason is that acids can be involved in other reactions, such as hydrolysis of carbohydrate during acid-catalysed in situ transesterification. Its involvement in such reaction may require high acid concentration to affect high FAME yield.

\subsection{In Situ Transesterification Using SDS $/ \mathrm{H}_{2} \mathrm{SO}_{4}$}

The amount of phospholipids and glycolipids in total lipids of $N$. occulata were determined as $50 \% \pm 0 \%$ (w/w total lipids) while that in total lipids of $C$. vulgaris were $30.3 \% \pm 1.3 \%$ (w/w total lipids). This was equivalent to $3.2 \mathrm{~mol} \mathrm{SDS} /(\mathrm{mol}$ total lipids) in N. occulata. In C. vulgaris, it was equivalent to $6.1 \mathrm{~mol} \mathrm{SDS} /(\mathrm{mol}$ total lipids). In both $N$. occulata and $C$. vulgaris, the amount of SDS in $\mathrm{H}_{2} \mathrm{SO}_{4}$ was significantly greater than 2 mol SDS/ (mol phospholipids) required to solubilise the phospholipids bilayers [26]. Sodium dodecyl sulphate (SDS) is a surfactant known for lysing cells to enhance extraction of intracellular components [15]. The effect of inclusion of SDS in $\mathrm{H}_{2} \mathrm{SO}_{4}$ on FAME yields for $N$. occulata and $C$. vulgaris is shown in Figure 3.

At $24 \mathrm{~h}$, a $72.6 \% \pm 7.7 \%$ maximum FAME yield was obtained in $N$. occulata. In contrast, a $53.8 \% \pm 8 \%$ FAME yield was obtained in this species at the same duration with $\mathrm{H}_{2} \mathrm{SO}_{4}$ alone. In C. vulgaris, at $24 \mathrm{~h}$, a maximum FAME yield of $75.6 \% \pm 8.7 \%$ was obtained with SDS plus $\mathrm{H}_{2} \mathrm{SO}_{4}$ catalyst, whereas the FAME yield was $57.5 \% \pm 3.6 \%$ when using $\mathrm{H}_{2} \mathrm{SO}_{4}$ alone. These FAME yields represent $35 \%$ and $31 \%$ increases for $N$. occulata and C. vulgaris, respectively. This is significantly higher than the $11 \%$ increase obtained by inclusion of cetyltrimethylammonium bromide (CTAB) (a surfactant) in $\mathrm{NaOH}$ for in situethanolysis of Jatropha curcas $\mathrm{L}$ [35], although it is difficult to ascribe this to the surfactant, given the difference in catalyst.

\subsection{In Situ Transesterification with Surfactant Catalyst ("ZDS") vs $\mathrm{H}_{2} \mathrm{SO}_{4}$}

The performance of a synthesized "surfactant catalyst” (zirconium dodecyl sulphate, or "ZDS”) for FAME production from $N$. occulata and C. vulgaris was investigated. The resultant time profiles are shown in Figure 4.

As can be seen in the figure in $N$. occulata, FAME production rate by ZDS was greater than that produced by $\mathrm{H}_{2} \mathrm{SO}_{4}$ between 12 - $36 \mathrm{~h}$. This is contrary to a reduction in FAME yield from $14 \%$ to $8 \%$ with increase in time 


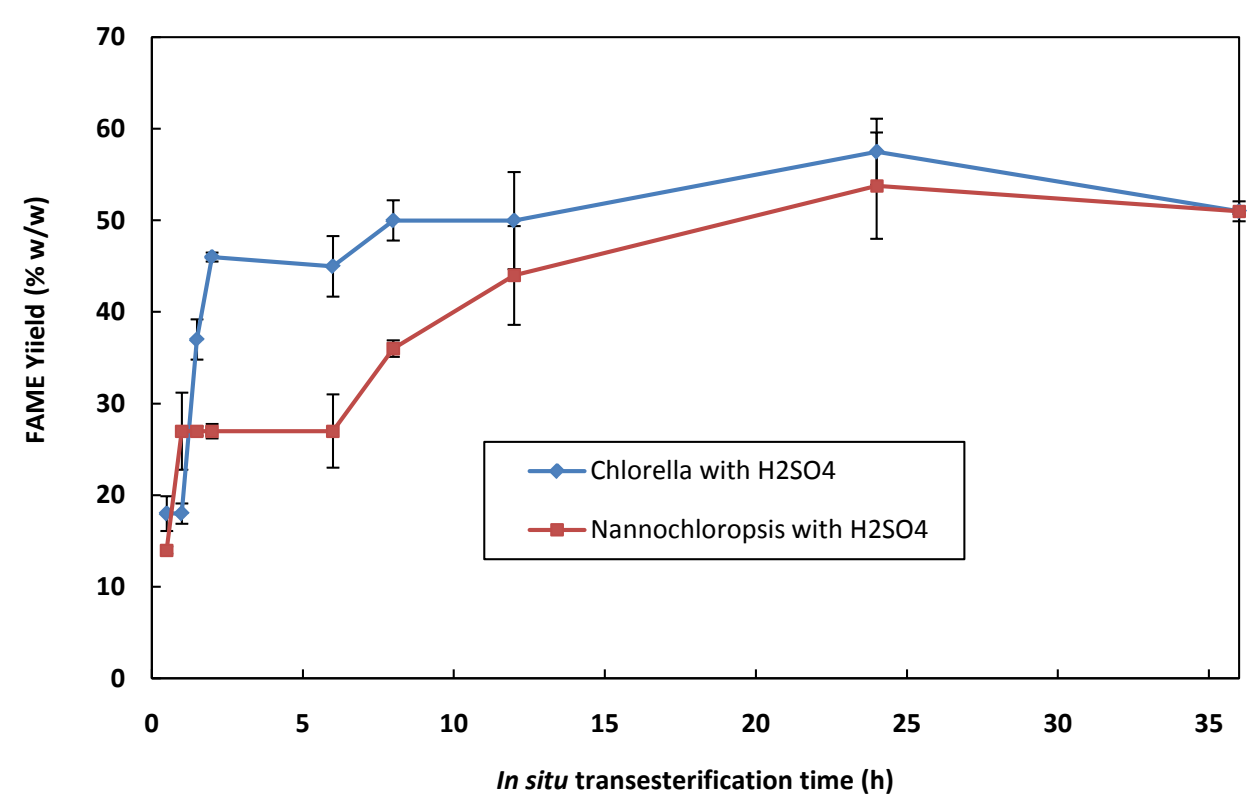

Figure 2. Reactively extracted FAME profile of $N$. occulata and C. vulgaris with $\mathrm{H}_{2} \mathrm{SO}_{4}$ catalyst. Process conditions: $600 \mathrm{~mol} \mathrm{methanol} /(\mathrm{mol}$ oil $)=0.47 \mathrm{~mL}$ methanol, agitation rate $=450$ $\mathrm{rpm}$, temperature $=60^{\circ} \mathrm{C}$, mass of microalgae $=100 \mathrm{mg}, 8.5 \mathrm{~mol} \mathrm{H}_{2} \mathrm{SO}_{4} /(\mathrm{mol} \mathrm{oil})=0.087$ $\mu \mathrm{L} /(\mathrm{mg}$ biomass).

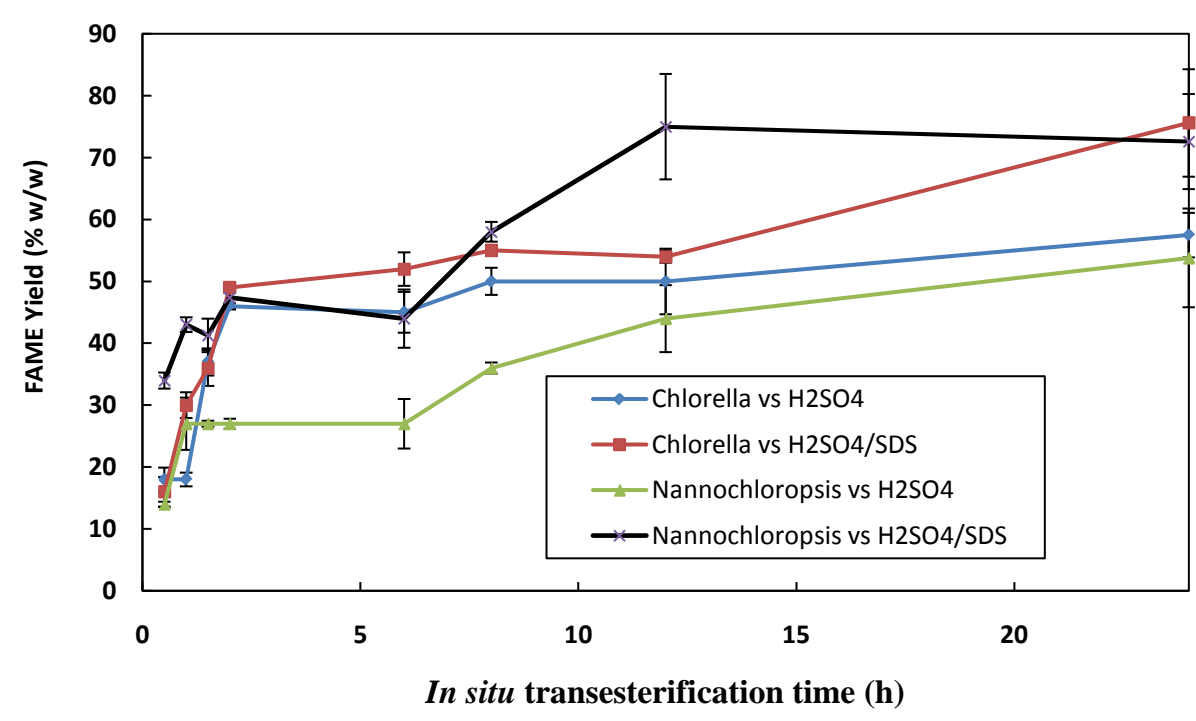

Figure 3. Reactively extracted FAME profile of $N$. occulata and $C$. vulgaris with $\mathrm{H}_{2} \mathrm{SO}_{4}$ vs SDS plus $\mathrm{H}_{2} \mathrm{SO}_{4}$. Process conditions: $600 \mathrm{~mol} \mathrm{methanol} /(\mathrm{mol}$ oil $)=0.47 \mathrm{~mL}$ methanol $/(\mathrm{mg}$ algae), $8.5 \mathrm{~mol} \mathrm{H}_{2} \mathrm{SO}_{4} /(\mathrm{mol} \mathrm{oil})=0.087 \mu \mathrm{L} /(\mathrm{mg}$ algae $)$, agitation rate $=450 \mathrm{rpm}$, temperature $=60^{\circ} \mathrm{C}$, mass of microalgae $=100 \mathrm{mg}$.

1.5 to $8 \mathrm{~h}$ observed in C. vulgaris with ZDS catalyst. This results conform with a reduction in FAME content from $15 \mathrm{mg}$ to $11 \mathrm{mg}$ [3] and from 3.4\% to 2\% [36]. Such FAME reduction has been ascribed to oligomerisation of unsaturated FAME, which can occur at $50^{\circ} \mathrm{C}$ [36]. A mineral or Lewis-acid has been reported to catalyse formation of triglycerides oligomers at $75^{\circ} \mathrm{C}$ [37]. ZDS is a Lewis acid-surfactant-combined catalyst and reduction in the FAME yield observed in Chlorella vulgaris using this catalyst could be due to FAME consumption via oligomerisation. It is also clear that the FAME production rate in Chlorella vulgaris when using $\mathrm{H}_{2} \mathrm{SO}_{4}$ was significantly greater than that of ZDS at each data point. The varying effect of ZDS on the $N$. occulata and $C$. vulgaris could be due to cell wall chemistry differences. Therefore, a more measurements should be directed to 


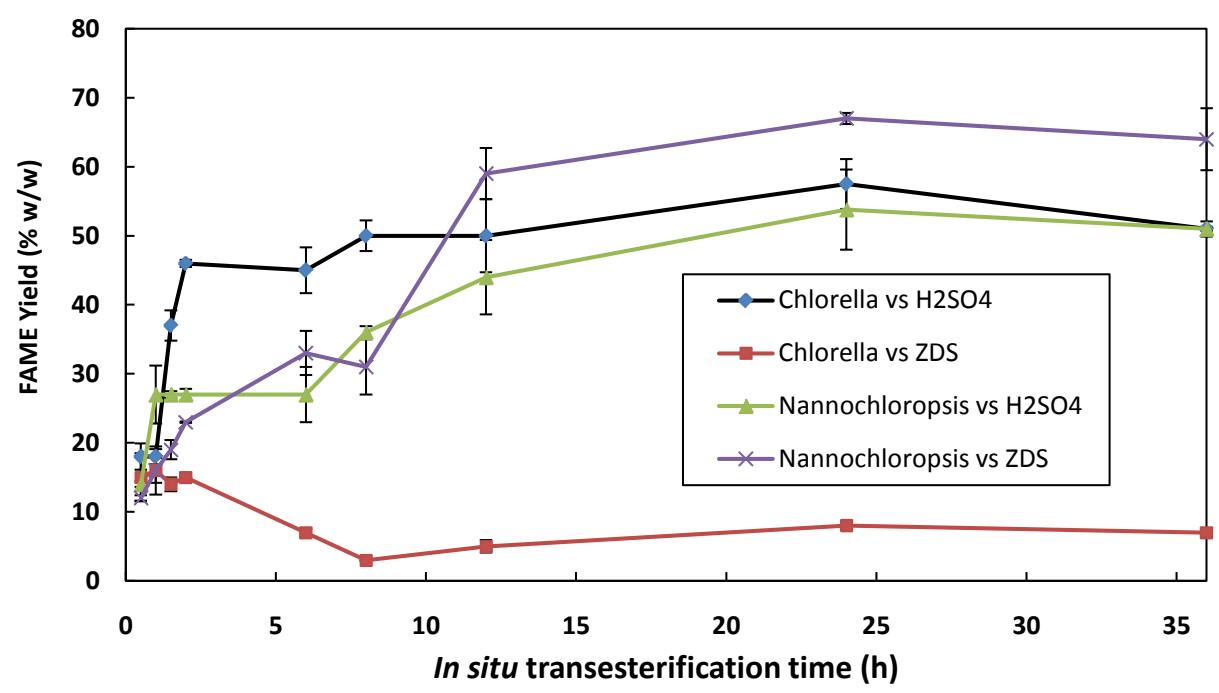

Figure 4. Reactively extracted FAME profile of $N$. occulata and $C$. vulgaris with ZDS. Process conditions: $600 \mathrm{~mol} \mathrm{methanol} /(\mathrm{mol} \mathrm{oil})=0.47 \mathrm{~mL}$ methanol $/(\mathrm{mg}$ algae $), 8.5 \mathrm{~mol}$ $\mathrm{H}_{2} \mathrm{SO}_{4} /(\mathrm{mol}$ oil $)=0.087 \mu \mathrm{L} /(\mathrm{mg}$ algae $), 18 \% \mathrm{ZDS} /($ mass algae $)$, mass of microalgae $=100 \mathrm{mg}$, agitation rate $=450 \mathrm{rpm}$, temperature $=60^{\circ} \mathrm{C}$.

detect the compounds producing FAME yield changes particularly non-hydrolysable macromolecules such as algaenans and sporopollenin.

The maximum FAME yields obtained in N. occulata and C. vulgaris are shown in Table 2 and Table 3. While Table 2 shows the maximum FAME yields obtained in both species using different catalysts, Table 3 shows the effect of the algae species on the FAME yield at a particular experimental condition.

$\mathrm{H}_{2} \mathrm{SO}_{4}$ concentration of 8.5 and $15 \mathrm{~mol} /\left(\mathrm{mol}\right.$ oil) was equivalent to $0.326 \mathrm{mmol} \mathrm{H}^{+}$and $0.578 \mathrm{mmol} \mathrm{H}^{+}$, respectively. As can be seen in the Table 2, increase in the acid concentration from 8.5 to $15 \mathrm{~mol} /(\mathrm{mol}$ oil) increased the FAME production rate in both species. This conform with what was observed in the literatures [3] [12] [34] but this could increase the operating cost as there will be the need to remove the unreacted acid from the product streams. The inclusion of SDS in $8.5 \mathrm{~mol} /\left(\mathrm{mol}\right.$ oil) $\mathrm{H}_{2} \mathrm{SO}_{4}$ at $20 \%$ moisture (w/w) dry algae produced $92.2 \% \pm 0.8 \%$ and $98 \% \pm 6.7 \%$ FAME yield in C. vulgaris and $N$. occulata respectively. This shows that SDS inclusion in $\mathrm{H}_{2} \mathrm{SO}_{4}$ reduces the catalyst concentration by $43 \%$ and increase the water tolerance of the process. This approach could improve the process economy. The maximum FAME yield produced at $15 \mathrm{~mol} /(\mathrm{mol}$ oil) was greater than that produced by ZDS. However, 100\% ZDS (w/w algal oil) used was equivalent to 0.0624 mmol $\mathrm{H}^{+}$indicating that ZDS is more efficient on a mass for mass basis than $\mathrm{H}_{2} \mathrm{SO}_{4}$, particularly for $N$. occulata.

As can be seen in Table 3 there is no significant different between the maximum FAME yield obtained in $C$. vulgaris and $N$. occulata when $\mathrm{H}_{2} \mathrm{SO}_{4}$ alone or $\mathrm{H}_{2} \mathrm{SO}_{4}+\mathrm{SDS}$ were used i.e. $(\mathrm{p}>0.05)$. However when $\mathrm{ZDS}$ was used, a maximum FAME yield of $67 \% \pm 1.1 \%$ was obtained in $N$. occulata which is significantly greater than $22 \% \pm 3 \%$ FAME yield obtained in C. vulgaris i.e. $(\mathrm{p}<0.05)$. The substantial differences exhibited by the two species when using ZDS could be due to their varying cell wall chemistry as explained in section 3.4.

A typical FAME chromatogram obtained from the experiment is shown in Figure 5. The first peak is the solvent (methanol) peak while the other largest peak is internal standard: methyl heptadecanoate (C: 17) peak. Other peaks are the FAME distribution range from C8:0 to C20:1.

\subsection{Effect of Inclusion of SDS in $\mathrm{H}_{2} \mathrm{SO}_{4}$ on Water Tolerance}

It has been shown that acid-catalysed direct transesterification exhibits higher water tolerance to microalgaebound water [34] and free water [3]. In order to investigate the level of water tolerance of $\mathrm{H}_{2} \mathrm{SO}_{4}$, with and without SDS, samples with $10 \%, 20 \%$ and $30 \%$ distilled water (w/w dry algae) were prepared and allowed to equilibrate for $1 \mathrm{~h}$. Surprisingly, there was an increase in the FAME rate for $\mathrm{H}_{2} \mathrm{SO}_{4}$, with or without SDS, with increase in moisture content in both microalgae, which is contrary to what has been reported for two-step transesterification (Figure 6 and Figure 7). 
Table 2. Maximum FAME yields from both species.

\begin{tabular}{|c|c|c|c|}
\hline Microalgae species & Catalyst & FAME yield $\%(w / w)$ & Reaction time (h) \\
\hline C. vulgaris & ${ }^{\mathrm{a}} \mathrm{H}_{2} \mathrm{SO}_{4}$ & $57.5 \pm 3.6$ & 24 \\
\hline C. vulgaris & ${ }^{\mathrm{b}} \mathrm{H}_{2} \mathrm{SO}_{4}$ & $67 \pm 1$ & 24 \\
\hline C. vulgaris & $\mathrm{SDS}+{ }^{\mathrm{c}} \mathrm{H}_{2} \mathrm{SO}_{4}$ & $72.6 \pm 7.7$ & 24 \\
\hline C. vulgaris & $\mathrm{SDS}+{ }^{\mathrm{d}} \mathrm{H}_{2} \mathrm{SO}_{4}$ & $92.2 \pm 0.8$ & 24 \\
\hline N. occulata & ${ }^{\mathrm{a}} \mathrm{H}_{2} \mathrm{SO}_{4}$ & $53.8 \pm 8$ & 24 \\
\hline N. occulata & ${ }^{\mathrm{b}} \mathrm{H}_{2} \mathrm{SO}_{4}$ & $87 \pm 2$ & 24 \\
\hline N. occulata & $\mathrm{SDS}+{ }^{\mathrm{c}} \mathrm{H} 2 \mathrm{SO} 4$ & $73 \pm 7.7$ & 24 \\
\hline N. occulata & $\mathrm{SDS}+{ }^{\mathrm{d}} \mathrm{H} 2 \mathrm{SO} 4$ & $98 \pm 6.7$ & 24 \\
\hline N. occulata & ZDS & $67 \pm 1$ & 24 \\
\hline
\end{tabular}

${ }^{\mathrm{a}} \mathrm{H}_{2} \mathrm{SO}_{4}=8.5 \mathrm{~mol} /\left(\mathrm{mol}\right.$ oil); ${ }^{\mathrm{b}} \mathrm{H}_{2} \mathrm{SO}_{4}=15 \mathrm{~mol} /(\mathrm{mol} \mathrm{oil}) ;{ }^{\mathrm{c}} \mathrm{H}_{2} \mathrm{SO}_{4}+\mathrm{SDS}: 8.5 \mathrm{H}_{2} \mathrm{SO}_{4} \mathrm{~mol} /\left(\mathrm{mol}\right.$ oil), dry algae; ${ }^{\mathrm{d}} \mathrm{H}_{2} \mathrm{SO}_{4}+\mathrm{SDS}: 8.5 \mathrm{H}_{2} \mathrm{SO}_{4} \mathrm{~mol} /(\mathrm{mol} \mathrm{oil})$, wet algae at $20 \%$ moisture (w/w dry algae). Process conditions: $600 \mathrm{~mol}$ methanol $/\left(\mathrm{mol}\right.$ oil), agitation rate $=450 \mathrm{rpm}$, temperature $=60^{\circ} \mathrm{C}$, mass of microalgae $=100 \mathrm{mg}, 9 \mathrm{mg}$ SDS, $100 \% \mathrm{ZDS}(\mathrm{w} / \mathrm{w}$ algal oil).

Table 3. Comparison between maximum FAME yields obtained in both species.

\begin{tabular}{|c|c|c|c|c|}
\hline Moisture: \% (w/w) dry algae & Microalgae & Catalyst & FAME Yield & $\mathrm{P}$ value \\
\hline \multirow[t]{2}{*}{0} & C. vulgaris & $\mathrm{H}_{2} \mathrm{SO}_{4}$ & $57.5 \pm 3.6$ & 0.428 \\
\hline & N. occulata & $\mathrm{H}_{2} \mathrm{SO}_{4}$ & $53.8 \pm 8$ & \\
\hline \multirow[t]{2}{*}{0} & C. vulgaris & ZDS & $22 \pm 3$ & 0.008 \\
\hline & N. occulata & ZDS & $67 \pm 1.1$ & \\
\hline \multirow[t]{2}{*}{0} & C. vulgaris & $\mathrm{H}_{2} \mathrm{SO}_{4}+\mathrm{SDS}$ & $72.6 \pm 7.7$ & 0.405 \\
\hline & N. occulata & $\mathrm{H}_{2} \mathrm{SO}_{4}+\mathrm{SDS}$ & $73 \pm 7.7$ & \\
\hline \multirow[t]{2}{*}{20} & C. vulgaris & $\mathrm{H}_{2} \mathrm{SO}_{4}+\mathrm{SDS}$ & $92.2 \pm 0.8$ & 0.164 \\
\hline & N. occulata & $\mathrm{H}_{2} \mathrm{SO}_{4}+\mathrm{SDS}$ & $98 \pm 6.7$ & \\
\hline
\end{tabular}

Process conditions: $\mathrm{H}_{2} \mathrm{SO}_{4}=8.5 \mathrm{~mol} /\left(\mathrm{mol}\right.$ oil); $\mathrm{H}_{2} \mathrm{SO}_{4}+\mathrm{SDS}: 8.5 \mathrm{H}_{2} \mathrm{SO}_{4} \mathrm{~mol} /(\mathrm{mol}$ oil); $600 \mathrm{~mol}$ methanol/(mol oil), agitation rate $=450 \mathrm{rpm}$, temperature $=60^{\circ} \mathrm{C}$, mass of microalgae $=100 \mathrm{mg}, 9 \mathrm{mg}$ SDS, $100 \%$ ZDS ( $/ \mathrm{w}$ algal oil).

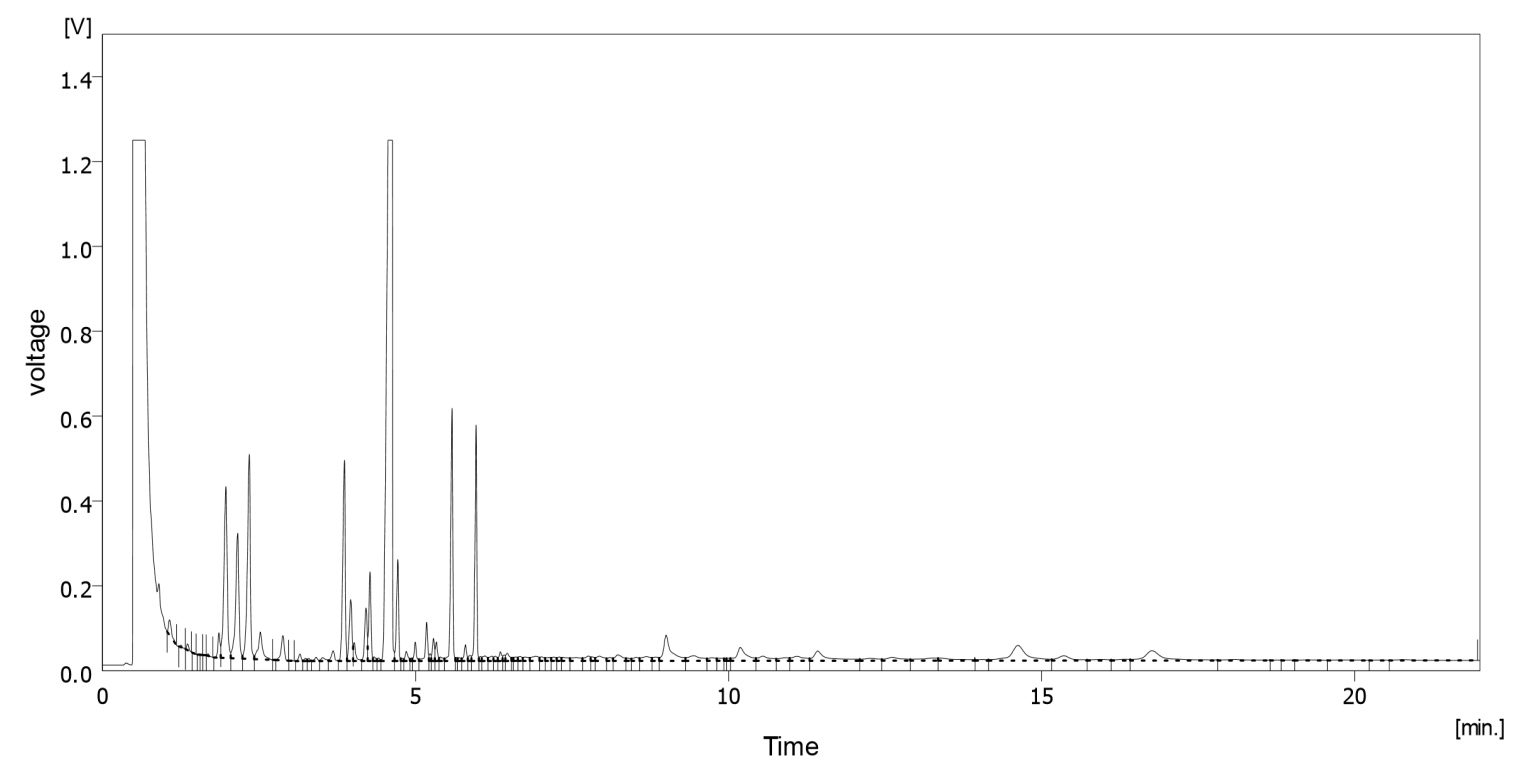

Figure 5. A typical FAME chromatogram obtained from the experiment. 


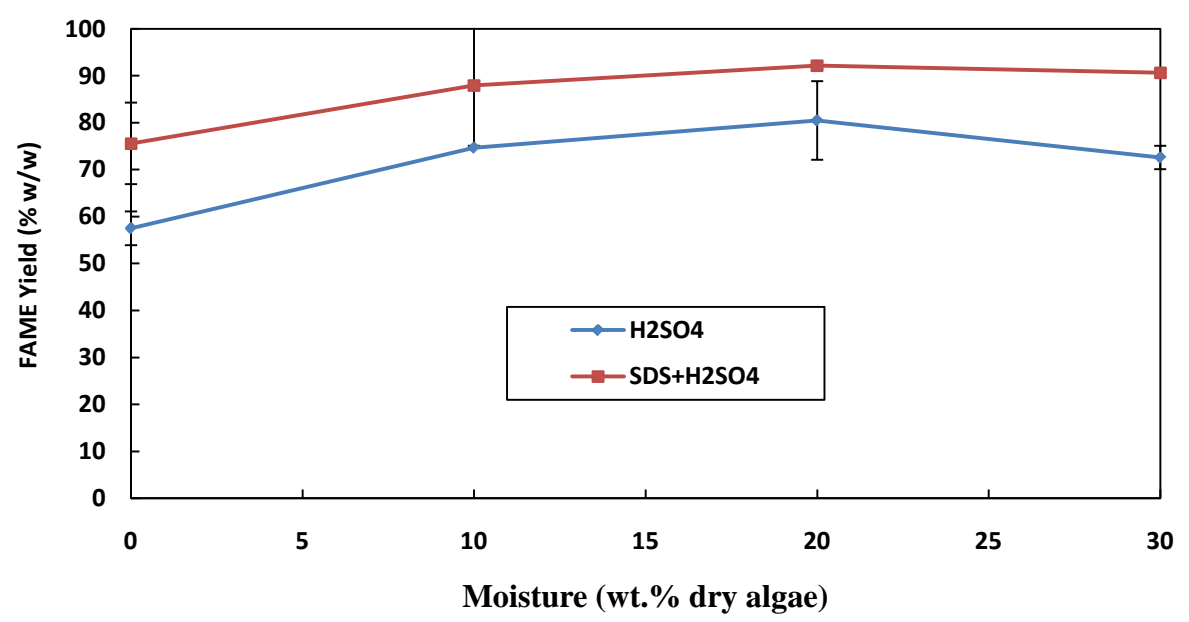

Figure 6. Reactively Extracted FAME produced from re-hydrated C. vulgaris with $\mathrm{H}_{2} \mathrm{SO}_{4}$ or $\mathrm{H}_{2} \mathrm{SO}_{4}+$ SDS. Process conditions: $600 \mathrm{~mol}$ methanol $/(\mathrm{mol}$ oil $)=0.47 \mathrm{~mL}$ methanol, $8.5 \mathrm{~mol}$ $\mathrm{H}_{2} \mathrm{SO}_{4} /(\mathrm{mol}$ oil $)=0.087 \mu \mathrm{L} /(\mathrm{mg}$ biomass $)$, agitation $=450 \mathrm{rpm}$, temperature $=60^{\circ} \mathrm{C}, 9 \mathrm{mg}$ SDS, mass of microalgae $=100 \mathrm{mg}$.

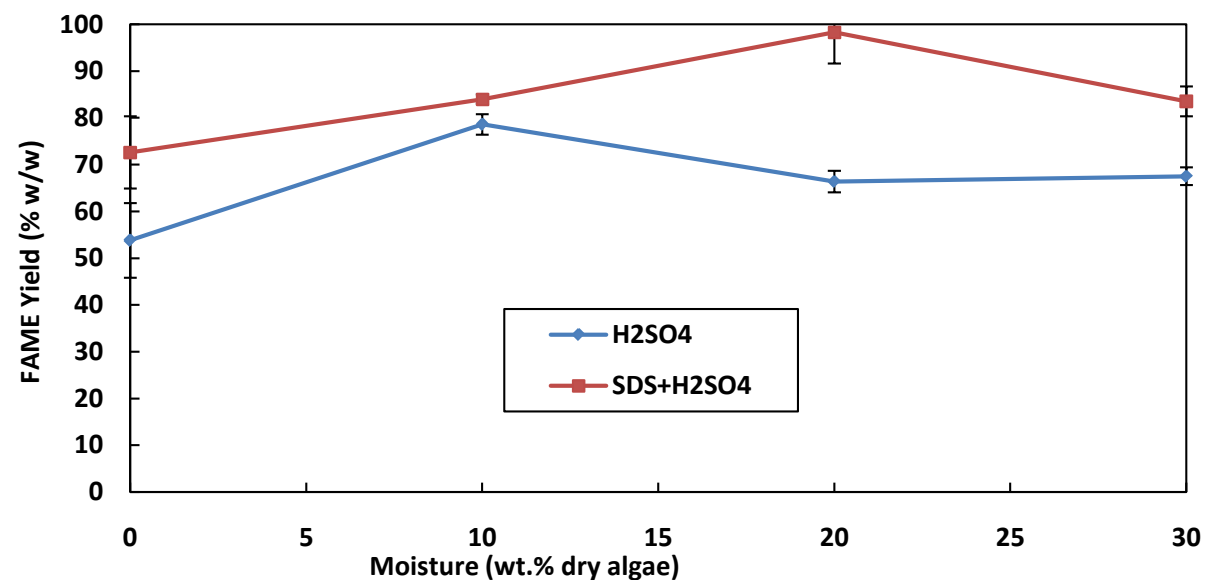

Figure 7. Reactively Extracted FAME produced from re-hydrated $N$. occulata with $\mathrm{H}_{2} \mathrm{SO}_{4}$ or $\mathrm{H}_{2} \mathrm{SO}_{4}+$ SDS. Process conditions: $600 \mathrm{~mol}$ methanol $/(\mathrm{mol}$ oil $)=0.47 \mathrm{~mL}$ methanol, $8.5 \mathrm{~mol}$ $\mathrm{H}_{2} \mathrm{SO}_{4} /(\mathrm{mol}$ oil $)=0.087 \mu \mathrm{L} /(\mathrm{mg}$ biomass $)$, agitation $=450 \mathrm{rpm}$, temperature $=60^{\circ} \mathrm{C}, 9 \mathrm{mg}$ SDS, mass of microalgae $=100 \mathrm{mg}$.

The FAME production rates begin to decrease at $20 \%$ moisture content. Cell wall lipids, such as phospholipids and glycolipids may be disrupted by polar organic solvents such as methanol, ethanol or other alcohols [38]. However, the poor permeability of these solvents into the cells of completely dry oil-bearing biomass can significantly reduce their lipid extraction efficiency [38]. This can be counteracted to some extent by addition of a small quantity of water, as it swells the cell wall. The inclusion of water in extracting solvents including methanol or ethanol has been reported to increase extraction of phospholipids [39]. Removal of the cell wall lipids (phospholipids and glycolipids) from the algal cell walls compromises their integrity i.e. it disrupts the cell wall to some degree thereby increasing accessibility of the solvent (methanol) to the internal body lipids (triglycerides). In addition, the interaction of water and methanol with cell wall proteins could compromise their integrity. The observed enhancement could be some combination of these two effects and the swelling effect. Therefore, the observed water tolerance in re-hydrated microalgae was probably due to increased lipid extraction by moist methanol. This could be a key method of increasing the FAME yield in in situ transesterification.

However, after $20 \%$ moisture content, a drop in the FAME yield was observed, which shows that the water tolerance has been exceeded for both catalysts. The amount of water tolerance achieved here is greater than $10 \%$ (w/w dry mass) obtained by Velasquez-orta et al. [34], perhaps because their moisture content was based on 
bound, rather than the free water used in this current investigation. However, the water tolerance achieved here is lower than the $50 \%$ (w/w dry mass) of free water during acid-catalysed in situ esterification of C. gracilius reported by Wahlen et al. [3]. It should be noted that Wahlen et al. [3], used a higher methanol volume, 0.04 $\mathrm{mL} /$ (mg algae), which was significantly higher than the $0.0047 \mathrm{~mL} /(\mathrm{mg}$ algae) used in this study. In situ esterification of microalgae using $\mathrm{H}_{2} \mathrm{SO}_{4}$ as catalyst exhibits the same water tolerance, with or without SDS.

\subsection{Mechanisms of Enhancement of FAME Yield by the Surfactant-Based Catalysts}

The difference in the FAME production by the catalysts is explained in terms of the chlorophyll extracts after the in situ transesterification of the different catalysts, as shown in Table 4.

Chlorophyll concentration has been positively correlated with cell wall disruption [23]. Based on this measurement, $\mathrm{H}_{2} \mathrm{SO}_{4}, \mathrm{H}_{2} \mathrm{SO}_{4}+\mathrm{SDS}$ and ZDS significantly disrupt the cells i.e. $(\mathrm{p}<0.05)$ than the control experiment in $N$. occulata. Similarly $\mathrm{H}_{2} \mathrm{SO}_{4}, \mathrm{H}_{2} \mathrm{SO}_{4}+\mathrm{SDS}$ significantly disrupt the cells i.e. $(\mathrm{p}<0.05)$ than the control experiment in $C$. vulgaris but there was no significant difference in cell wall disruption between ZDS and the control experiment in C. vulgaris which explains why ZDS produced low yield in this species. In contrast, the highest chlorophyll extract was produced when using ZDS in $N$. occulata. Clearly, ZDS disrupts $N$. occulata's cell wall more than $\mathrm{H}_{2} \mathrm{SO}_{4}$ which explains why it produced greater FAME yield than $\mathrm{H}_{2} \mathrm{SO}_{4}$ alone. Again, the difference in the behaviours exhibited by this catalyst towards both microalgae could be explained by the difference in the cell wall chemistry of the two species as explained in section 3.4.

\subsection{Carbohydrate and Protein Content before and after in Situ Transesterification}

The protein and carbohydrate contents of the residual algal biomass were measured at the maximum FAME yield as shown in Figure 8.

It can be seen that protein is retained at all conditions, and carbohydrate significantly reduced. This implies that a substantial portion of the carbohydrate was hydrolysed to simple sugars or other associated products that dissolved in water/methanol mixture. The protein retention is probably desirable, as it means that the residue can be utilised for biogas generation. However, it is anticipated that Carbon/Nitrogen $(\mathrm{C} / \mathrm{N})$ will be will be low due to high content of protein and low content of residual carbohydrate. In order to utilise this substrate efficiently as feed for biogas production, it is necessary to co-digest it with high $\mathrm{C} / \mathrm{N}$ substrate to reach an optimum $\mathrm{C} / \mathrm{N}$ ratio [40]. This approach could contribute to improvement in the process economy of the in situ transesterification of microalgae oil.

\section{Conclusion}

In situ transesterification has been shown to be technically feasible for FAME production from N. occulata and C. vulgaris using $\mathrm{H}_{2} \mathrm{SO}_{4}$, ZDS and $\mathrm{H}_{2} \mathrm{SO}_{4} / \mathrm{SDS}$ (a surfactant). ZDS produced significantly higher FAME yield $N$. occulata $(67 \% \pm 1 \%)$ than in C. vulgaris $(22 \% \pm 3 \%)$ i.e. $(\mathrm{p}<0.05)$. Differences in the activity of the ZDS in the two species are probably due to differences in their cell wall chemistry. SDS addition to $\mathrm{H}_{2} \mathrm{SO}_{4}$ enhances the

Table 4. Chlorophyll content as a measure of cell disruption in both species.

\begin{tabular}{cccc}
\hline Microalgae & Catalyst & Total chlorophyll $(\mu \mathrm{g} / \mathrm{mL})$ & P value \\
C. vulgaris & Control & $1.05 \pm 0.06^{\mathrm{a}}$ & - \\
C. vulgaris & Acid & $3.43 \pm 0.40^{\mathrm{a}}$ & 0.040 \\
C. vulgaris & Acid+SDS & $3.55 \pm 0.03^{\mathrm{a}}$ & 0.003 \\
C. vulgaris & ZDS & $0.61 \pm 0.09^{\mathrm{a}}$ & -056 \\
N. occulata & Control & $0.59 \pm 0.02^{\mathrm{b}}$ & 0.010 \\
N. occulata & Acid & $2.68 \pm 0.19^{\mathrm{b}}$ & 0.030 \\
N. occulata & Acid+SDS & $2.74 \pm 0.19^{\mathrm{b}}$ & 0.030
\end{tabular}

${ }^{\mathrm{a}}$ Total chlorophyll A + B; ${ }^{\mathrm{b}}$ Total chlorophyll A + C. Process conditions: $600 \mathrm{~mol}$ methanol/(mol lipids) $=0.47 \mathrm{~mL}$ methanol, $8.5 \mathrm{~mol} \mathrm{H} \mathrm{SO}_{4} /(\mathrm{mol}$ lipids $)=0.087 \mu \mathrm{L} \mathrm{H}_{2} \mathrm{SO}_{4} /(\mathrm{mg}$ algae $)$, agitation $=450 \mathrm{rpm}$, temperature $=32^{\circ} \mathrm{C}$, mass of microalgae $=100 \mathrm{mg}$, mass of SDS $=9 \mathrm{mg}, 100 \% \mathrm{ZDS} /(\mathrm{w} / \mathrm{w}$ lipids), reaction time $=24 \mathrm{~h}$. The control experiment contained no catalyst but other conditions were the same. 


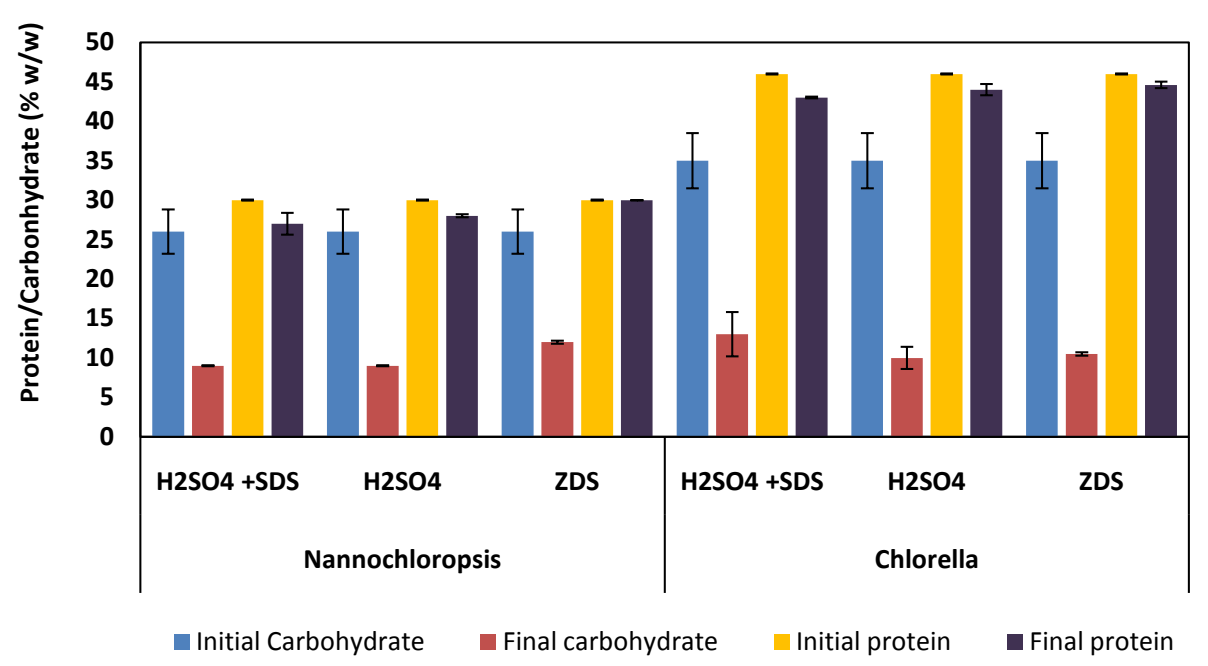

Figure 8. Carbohydrate and protein content of the microalgae before and after in situ transesterification.

FAME yield from both species and causes some level of water tolerance in both. Addition of SDS in $\mathrm{H}_{2} \mathrm{SO}_{4}$ at $20 \%$ moisture content produced a maximum FAME yield of $98.3 \% \pm 6.7 \%$ and $92.2 \% \pm 0.8 \%$ in $N$. occulata and $C$. vulgaris respectively. The residual biomass, regardless of the catalyst and/or surfactant, maintains the initial protein, indicating that the residue could be a valuable feed for anaerobic digester for producing biogas. Carbohydrate in the algal residue decreased significantly in all cases possibly due to its hydrolysis by the catalysts. This may represent the basis of a technique for separating the carbohydrate from the biomass for use in bioethanol production or aqueous phase reforming. Finally, not only is the process more tolerant to water than transesterification-based routes, but the presence of a small quantity of external water increases the FAME yields in in situ transesterification, rather than inhibiting the reaction. This effect was apparent for all conditions up to 20 - 30 wt.\% water/(wt. dry algae), and should substantially improve the economics of this process, as the energy required for drying algae to the conditions required for conventional biodiesel production ( $<0.5 \mathrm{w} \%$ water/w oil) is a substantial obstacle to economic operation.

\section{References}

[1] Zeng, J., Wang, X., Zhao, B., Sun, J. and Wan, Y. (2008) Rapid in Situ Transesterification of Sunflower Oil. Industrial \& Engineering Chemistry Research, 48, 850-856. http://dx.doi.org/10.1021/ie8008956

[2] Kasim, F.H. and Harvey, A.P. (2011) Influence of Various Parameters on Reactive Extraction of Jatropha curcas L. for Biodiesel Production. Chemical Engineering Journal, 171, 1373-1378. http://dx.doi.org/10.1016/j.cej.2011.05.050

[3] Wahlen, B.D., Willis, R.M. and Seefeldt, L.C. (2011) Biodiesel Production by Simultaneous Extraction and Conversion of Total Lipids from Microalgae, Cyanobacteria, and Wild Mixed-Cultures. Bioresource Technology, 102, 27242730. http://dx.doi.org/10.1016/j.biortech.2010.11.026

[4] Velasquez-orta, S.B., Lee, J.G.M. and Harvey, A. (2012) Alkaline in Situ Transesterification of Chlorella vulgaris. Fuel, 94, 544-550. http://dx.doi.org/10.1016/j.fuel.2011.11.045

[5] Salam, K.A., Velasquez-orta, S.B. and Harvey, A.P. (2016) Kinetics of Fast Alkali Reactive Extraction/in Situ Transesterification of Chlorella vulgaris That Identified Process Condition for a Significant Enhanced Rate and Water Tolerance. Fuel Processing Technology, 144, 212-219. http://dx.doi.org/10.1016/j.fuproc.2015.12.031

[6] Chisti, Y. (2007) Biodiesel from Microalgae. Biotechnology Advances, 25, 294-306. http://dx.doi.org/10.1016/j.biotechadv.2007.02.001

[7] Lardon, L., Sialve, B., Steyer, J. and Bernard, O. (2009) Life-Cycle Assessment of Biodiesel Production from Microalgae. Environmental Science \& Technology, 17, 6475-6481. http://dx.doi.org/10.1021/es900705j

[8] Chisti, Y. (2013) Constraints to Commercialization of Algal Fuels. Journal of Biotechnology, 167, 201-214. http://dx.doi.org/10.1016/j.jbiotec.2013.07.020

[9] Salam, K.A., Velasquez-orta, S.B. and Harvey, A.P. (2016) Surfactant Assisted Direct Biodiesel Production from Wet Nannochloropsis occulata by in Situ Transesterification/Reactive Extraction. Biofuel Research Journal, 9, 366-371. 
http://dx.doi.org/10.18331/BRJ2016.3.1.6

[10] Zhao, B., Ma, J., Zhao, Q., Laurens, L., Jarvis, E., Chen, S. and Frear, C. (2014), Efficient Anaerobic Digestion of Whole Microalgae and Lipid Extracted Microalgae Residues for Methane Energy Production. Bioresource Technology, 161, 423-430.

[11] Ehimen, E.A., Connaughton, S., Sun, Z. and Carrington, G.C. (2009) Energy Recovery from Lipid Extracted, Transesterified and Glycerol Codigested Microalgae Biomass. GCB Bioenergy, 1, 371-381. http://dx.doi.org/10.1111/j.1757-1707.2009.01029.x

[12] El-Shimi, H.I., Attia, N.K., El-Sheltawy, S.T. and El-Diwani, G.I. (2013) Biodiesel Production from Spirulina-Platensis Microalgae by In-Situ Transesterification Process. Journal of Sustainable Bioenergy Systems, 3, 224-233. http://dx.doi.org/10.4236/jsbs.2013.33031

[13] Ghesti, G.F., Macedo, J.L., Parente, V.C.I., Dias, J.A. and Dias, S.C.L. (2009) Synthesis, Characterization and Reactivity of Lewis Acid/Surfactant Cerium Trisdodecylsulfate Catalyst for Transesterification and Esterification Reactions. Applied Catalysis A: General, 355, 139-147. http://dx.doi.org/10.1016/j.apcata.2008.12.008

[14] Tuntiwiwattanapun, N., Tongcumpou, C., Haagenson, D. and Wiesenborn, D. (2013) Development and Scale-Up of Aqueous Surfactant-Assisted Extraction of Canola Oil for Use as Biodiesel Feedstock. Journal of the American Oil Chemists' Society, 90, 1089-1099. http://dx.doi.org/10.1007/s11746-013-2237-9

[15] Brown, R.B. and Audet, J. (2008) Current Techniques for Single-Cell Lysis. Journal of the Royal Society Interface, 5, S131-S138. http://dx.doi.org/10.1098/rsif.2008.0009.focus

[16] Canakci, M. and Gerpen, V.J. (1999) Biodiesel Production via Acid Catalysis. American Society of Agricultural and Biological Engineers, 42, 1203-1210. http://dx.doi.org/10.13031/2013.13285

[17] Widjaja, A., Chien, C. and Ju, Y. (2009) Study of Increasing Lipid Production from Fresh Water Microalgae Chlorella vulgaris. Journal of the Taiwan Institute of Chemical Engineers, 40, 13-20. http://dx.doi.org/10.1016/j.jtice.2008.07.007

[18] Folch, J., Lees, M. and Stanley, G.H.S. (1957) A Simple Method for the Isolation and Purification of Total Lipids from Animal Tissue. The Journal of Biological Chemistry, 226, 497-509.

[19] Gerhardt, P., Murray, R.G.E., Wood, W.A. and Krieg, N.R. (1994) Methods and Molecular Bacteriology. ASM, Washington DC.

[20] Lourenc, S.O., Barbarino, E., Lavin, P.L., Marquez, U.M.L. and Aidar, E. (2004) Distribution of Intracellular Nitrogen in Marine Microalgae: Calculation of New Nitrogen-to-Protein Conversion Factors. European Journal of Phycology, 39, 17-32. http://dx.doi.org/10.1080/0967026032000157156

[21] Kaluzny, M.A., Duncan, L.A., Merritt, M.V. and Epps, D.E. (1985) Rapid Separation of Lipid Classes in High Yield and Purity Using Bonded Phase Columns. The Journal of Lipid Research, 26, 135-140.

[22] Garces, R. and Mancha, M. (1993) One-Step Lipid Extraction and Fatty Acid Methyl Esters Preparation from Fresh Plant Tissues. Analytical Biochemistry, 211, 139-143. http://dx.doi.org/10.1006/abio.1993.1244

[23] Gerde, J.A., Montalbo-Lomboy, M., Yao, L., Grewell, D. and Wanga, T. (2012) Evaluation of Microalgae Cell Disruption by Ultrasonic Treatment. Bioresource Technology, 125, 175-181. http://dx.doi.org/10.1016/j.biortech.2012.08.110

[24] Jeffery, S.W. and Humphrey, G.F. (1975) New Spectrophotometric Equations for Determining Chlorophylls $a$, $b, c_{1}$, and $c_{2}$ in Higher Plants, Algae and Natural Phytoplankton. Biochemie und Physiologie der Pflanzen, 167, 191-194.

[25] Ehimen, E.A., Sun, Z.F. and Carrington, C.G. (2010) Variables Affecting the in Situ Transesterification of Microalgae Lipids. Fuel, 89, 677-684. http://dx.doi.org/10.1016/j.fuel.2009.10.011

[26] Tan, A., Ziegler, A., Steinbauer, B. and Seelig, J. (2002) Thermodynamics of Sodium Decylsulfate Partitioning into Lipid Membranes. Biophysical Journal, 83, 1547-1556. http://dx.doi.org/10.1016/S0006-3495(02)73924-6

[27] Haas, M.J. and Wagner, K.A. (2011) Process Model to Estimate Biodiesel Production Costs. European Journal of Lipid Science and Technology, 113, 1219-1229. http://dx.doi.org/10.1002/ejlt.201100106

[28] European Standard (2003) Fat and Oil Derivatives-Fatty Acid Methyl Esters (FAME)-Determination of Ester and Linolenic Acid Methyl Ester Contents. EN 14103: 2003.

[29] Zolfigol, M.A., Salehi, P., Shiri, M. and Tanbakouchian, Z. (2007) A New Catalytic Method for the Preparation of Bis-Indolyl and Tris-Indolylmethanes in Aqueous Media. Catalysis Communications, 8, 173-178. http://dx.doi.org/10.1016/j.catcom.2006.06.012

[30] Machida, M., Kawamura, K., Kawano, T., Zhang, D. and Ikeue, K.J. (2006) Layered Pr-Dodecyl Sulfate Mesophases as Precursors of $\mathrm{Pr}_{2} \mathrm{O}_{2} \mathrm{SO}_{4}$ Having a Large Oxygen-Storage Capacity. Journal of Materials Chemistry, 16, 3084-3090. http://dx.doi.org/10.1039/b605518d

[31] Socrates, G. (1994) Infrared Characteristics Group Frequency: Table and Charts. 2nd Edition, John Wiley and Sons, Chichester. 
[32] Kartha, V.B., Leitch, L.C. and Mantsch, H.H. (1984) Infrared and Raman Spectra of Alkali Palmityl Sulfates. Canadian Journal of Chemistry, 62, 128-132. http://dx.doi.org/10.1139/v84-025

[33] Lotero, E., Liu, Y., Lopez, D.E., Suwannakarn, K., Bruce, D.A. and Goodwin Jr., J.G. (2005) Synthesis of Biodiesel via Acid Catalysis. Industrial \& Engineering Chemistry Research, 44, 5353-5363. http://dx.doi.org/10.1021/ie049157g

[34] Velasquez-orta, S.B., Lee, J.G.M. and Harvey, A. (2013) Evaluation of FAME Production from Wet Marine and Freshwater Microalgae by in Situ Transesterification. Biochemical Engineering Journal, 76, 83-89. http://dx.doi.org/10.1016/j.bej.2013.04.003

[35] Hailegiorgis, S.M., Mahadzir, S. and Subbarao, D. (2011) Enhanced in Situ Ethanolysis of Jatropha curcas L. in the Presence of Cetyltrimethylammonium Bromide as a Phase Transfer Catalyst. Renewable Energy, 36, 2502-2507. http://dx.doi.org/10.1016/j.renene.2011.03.001

[36] Revellame, E., Hernandez, R., French, W., Holmes, W. and Alley, E. (2010) Biodiesel from Activated Sludge through in Situ Transesterification. Journal of Chemical Technology and Biotechnology, 85, 614-620. http://dx.doi.org/10.1002/jctb.2317

[37] Isbell, T.A. and Cermak, S.C. (2002) Synthesis of Triglyceride Estolides from Lesquerella and Castor Oils. Journal of the American Oil Chemists' Society, 79, 1227-1233. http://dx.doi.org/10.1007/s11746-002-0632-1

[38] Cohen, Z. (1999) Chemicals from Microalgae. Taylor and Francis Limited, London.

[39] Zhukov, A.V. and Vereshchagrin, A.G. (1981) Current Techniques of Extraction, Purification and Preliminary Fractionation of Polar Lipids of Natural Origin. Advances in Lipid Research, 18, 247-282.

[40] Yen, H.-W. and Brune, D.E. (2007) Anaerobic Co-Digestion of Algal Sludge and Waste Paper to Produce Methane. Bioresource Technology, 98, 130-134. http://dx.doi.org/10.1016/j.biortech.2005.11.010 